\title{
Comparison of conventional Papanicolaou smear and liquid-based cytology: a study of cervical cancer screening at a tertiary care centre in Bengaluru
}

\author{
Chaitra Krishna $^{1 *}$, Savitha Chandraiah ${ }^{2}$, Chandana Krishna ${ }^{3}$
}

${ }^{1}$ Community Health Centre, Thymagondlu, Nelamangala Tq, Bangalore Rural, Karnataka, India

${ }^{2}$ Department of Obstetrics and Gynaecology, Bangalore Medical College and Research Institute, Bangalore, Karnataka, India

${ }^{3}$ Community Medicine, Sri Siddhartha Medical College, Agalkote, Tumkur, Karnataka, India

Received: 18 June 2021

Accepted: 13 July 2021

\author{
*Correspondence: \\ Dr. Chaitra Krishna, \\ E-mail: chaitrambbs@gmail.com
}

Copyright: ( $)$ the author(s), publisher and licensee Medip Academy. This is an open-access article distributed under the terms of the Creative Commons Attribution Non-Commercial License, which permits unrestricted non-commercial use, distribution, and reproduction in any medium, provided the original work is properly cited.

\begin{abstract}
Background: Cervical cancer is the fourth commonest cancer affecting women worldwide and the second most common cancer in women aged 15-44 years. The Papanicolaou (Pap) smear has been the cornerstone of screening for cervical neoplasm for the last 50 years. Liquid-based cytology (LBC) was introduced in mid-1990s as an alternative technique to process cervical samples has many benefits over Pap. A new second generation technique, Liquiprep was introduced after a decade has the advantage of a much lower cost. However, the information available on second generation liquid based cytology is limited. The objective was to look for the efficacy of LBC and to compare it to that of conventional cytology.

Methods: This hospital based comparative study was undertaken 100 women who attended gynaecology OPD during 2017 at a tertiary care hospital in Bengaluru. Two cervical smears were simultaneously prepared from each subject, one for Pap smear and another for LBC followed by colposcopy and biopsy.

Results: Among the study subjects, $89 \%$ of Pap smear analysis and $100 \%$ of smears in LBC showed satisfactory smear. Cytological abnormality was detected in $11 \%$ and $21 \%$ in pap and LBC, respectively. The present study showed higher sensitivity and specificity of $100 \%$ and $75 \%$ by LBC when compared to Pap smear (55\% and 100\% respectively).

Conclusions: The present study showed that liquid based cytology is better in detecting cervical lesions when compared to conventional smear.
\end{abstract}

Keywords: Papanicolaou smear, Liquid-based cytology, Cervical cancer, Screening, Tertiary care centre

\section{INTRODUCTION}

Cervical cancer is the fourth commonest cancer affecting women worldwide and has also the seventh position of all malignancies. It is the second most common cancer in women between 15 and 44 years of age. ${ }^{1}$ Almost $70 \%$ of the global burden of cervical cancer falls in areas with lower levels of development and more than one-fifth of all new cases are diagnosed in India. For women in India, cervical cancer is the second most common cancer. It is the second most common cause of cancer deaths when both genders are combined. ${ }^{2}$

Frequently performed cytology screening programs have led to a decline in cervical cancer incidence and mortality in developed countries. In contrast, cervical cancer remains largely uncontrolled in high-risk developing countries because of ineffective or no screening program. ${ }^{3}$ 
The Papanicolaou (Pap) smear has been the cornerstone of screening for cervical neoplasm for the last 50 years. ${ }^{4}$ But the accuracy of this important screening tool remains controversial. Several recent meta-analyses have reported quite low Pap smear sensitivities, in the range of $50 \%$ but as low as $20 \% .^{5}$

LBC was introduced in mid-1990s as an alternative technique to process cervical samples. LBC is proposed to have many benefits over CPS such as less number of unsatisfactory (U/S) smears. ${ }^{6}$ More representative transfer of cells from collecting device, evenly distributed cellular material, the choice of using residual cellular material for human papillomavirus (HPV) testing, reduced screening time and possibly higher rate of high grade squamous intraepithelial lesion (HSIL) detection.

Reviews of published studies indicate that liquid based cytology is probably more sensitive than Pap smear in detecting cervical neoplasia and it improves sample adequacy. ${ }^{7}$ However, this first generation LBC technology requires an automated instrument which leads to increased costs.

A new second generation technique, Liquiprep was introduced after a decade of the advent of liquid based cytology, this had the advantage of a much lower cost. However, the information available on second generation LBC is limited.

Hence this study intended to look for the efficacy of LBC and to compare it to that of conventional cytology.

\section{Objectives}

The objectives of this study were to describe the sociodemographic characteristics of study subjects, to compare the adequacy of the smear of conventional Pap smear and LBC, to compare the efficacy of conventional Pap smear and LBC for the detection of cervical cancer and to compare the sensitivity, specificity and predictive values of conventional Pap smear cytology and LBC with cervix biopsy.

\section{METHODS}

This hospital based cross-sectional study was conducted at the department of obstetrics and gynaecology, at a tertiary care hospital in Bengaluru.

The study was conducted on 100 women who attended gynaecology OPD with symptoms and signs highly suspicious for cervical malignancy.

\section{Inclusion criteria}

Women with symptoms like abnormal vaginal discharge, post-coital bleeding, post-menopausal bleeding, intermenstrual bleeding were included in the study. Women in whom cervix appeared unhealthy on speculum examination like hypertrophy, redness or congestion, irregular surface and erosions were also included in the study.

\section{Exclusion criteria}

Pregnant women, women with frank growth over the cervix and/or who had never been sexually active, women with active vaginal bleeding, hysterectomized women and those who had undergone prior treatment for CIN or cancer cervix were excluded from the study.

\section{Methodology}

After obtaining clearance from the institutional ethical committee, the study subjects who fulfilled the inclusion and exclusion criteria were recruited for the study. After obtaining proper consent, all the study participants were evaluated by detailed clinical history and physical examination. Pap smear specimen was collected by an Ayers spatula and smeared on a slide and fixed with $95 \%$ of ethanol (conventional Pap smear cytology (CPAP). LBC was done using cytobrush specimen and was collected in a vial containing preservative for liquid-based preparation.

All the patients who have abnormal findings in exfoliative cytology are subjected for colposcopy. Cervix was cleared off the mucous discharge using a swab soaked in normal saline initially. Later cervix was gently wiped with $3 \%$ acetic acid and the examination repeated and is looked for abnormal aceto-white areas. Then Lugol's iodine is applied all over the cervix and looked for abnormal iodine negative areas. Any abnormal or suspicious lesions like aceto-white areas or iodine negative areas or abnormal vessels were noted and cervical biopsy was taken from these areas and the sample is sent for histopathological examination. If colposcopy did not show any suspicious lesions, it was considered normal and biopsy was deferred in these cases.

\section{RESULTS}

\section{Sociodemographic profile of study subjects}

Among the study subjects, majority were in the age group of 30-40 years, were illiterates and from urban area. Majority of subjects were pre-menopausal, with 1-2 parity. 11-20 years were the age at marriage and majority were using OCPs for family planning. Majority were having normal BMI (Table 1).

\section{Presenting complaints and co-morbidities among the study subjects}

Abnormal vaginal discharge was the most common presenting complaint seen in 59\% of study subjects. Postmenopausal bleeding was the most common menstrual abnormality. Unhealthy cervix was seen in $76 \%$ of study subjects (Table 2). 
Table 1: Socio-demographic profile of study subjects.

\begin{tabular}{|c|c|c|}
\hline Characteristics & & Number (percentage) \\
\hline \multirow{5}{*}{ Age (in years) } & $30-40$ & $56(56.0)$ \\
\hline & $41-50$ & $23(23.0)$ \\
\hline & $51-60$ & $16(16.0)$ \\
\hline & $61-70$ & $4(4.0)$ \\
\hline & $>70$ & $1(1.0)$ \\
\hline \multirow{5}{*}{ Education } & Illiterate & $43(43.0)$ \\
\hline & $1-7$ & $13(13.0)$ \\
\hline & $8-10$ & $13(13.0)$ \\
\hline & $11-12$ & $10(10.0)$ \\
\hline & Degree+ & $21(21.0)$ \\
\hline \multirow{2}{*}{ Domicile } & Rural & $3636.0)$ \\
\hline & Urban & $64(64.0)$ \\
\hline \multirow{2}{*}{ Menopausal status } & Pre-menopausal & $72(72.0)$ \\
\hline & Menopausal & $28(28.0)$ \\
\hline \multirow{5}{*}{ Parity } & 0 & $3(3.0)$ \\
\hline & $1-2$ & $53(53.0)$ \\
\hline & $3-5$ & $41(41.0)$ \\
\hline & $6-10$ & $3(3.0)$ \\
\hline & No & 94 (94.0) \\
\hline \multirow{2}{*}{ Age at marriage (in years) } & $11-20$ & $63(63.0)$ \\
\hline & $20-30$ & $37(37.0)$ \\
\hline \multirow{3}{*}{ Family planning method } & OCP use & $7(7.0)$ \\
\hline & Barrier method & $3(3.0)$ \\
\hline & IUCD & $5(5.0)$ \\
\hline \multirow{4}{*}{ BMI $\left(\mathrm{kg} / \mathbf{m}^{2}\right)$} & $<18.5$ & $13(13.0)$ \\
\hline & $18.5-25$ & $56(56.0)$ \\
\hline & $25-30$ & $30(30.0)$ \\
\hline & $>30$ & $1(1.0)$ \\
\hline
\end{tabular}

Table 2: Presenting complaints and co-morbidities among the study subjects.

\begin{tabular}{|lll|}
\hline Characteristics & & Number (percentage)* \\
\hline Abnormal vaginal discharge & & $59(59.0)$ \\
\hline Pain abdomen & & $32(32.0)$ \\
\hline Post-coital bleeding & & $14(14.0)$ \\
\hline \multirow{3}{*}{ Menstrual abnormalities } & Post-menopausal bleeding & $16(16.0)$ \\
\cline { 2 - 3 } & Menstrual disturbances & $12(12.0)$ \\
\cline { 2 - 3 } Loss of weight and appetite & Inter menstrual bleeding & $15(15.0)$ \\
\hline \multirow{3}{*}{ Co-morbidities } & Loss of weight & $3(3.0)$ \\
\cline { 2 - 3 } & Loss of appetite & $10(10.0)$ \\
\hline STD/genital warts & Diabetes & $3(3.0)$ \\
\hline Unhealthy cervix & HIV & $5(5.0)$ \\
\hline & HTN & $1(1.0)$ \\
\hline
\end{tabular}

*Multiple responses.

Table 3: Distribution of study subjects based on adequacy of smear.

\begin{tabular}{|lll|}
\hline Tests & Characteristics & Number (percentage) \\
\hline \multirow{3}{*}{ Pap smear } & Pap smear satisfactory & $89(89.0)$ \\
\cline { 2 - 3 } & Pap smear air artifact & $9(9.0)$ \\
\cline { 2 - 3 } & Pap smear bloody smear & $18(18.0)$ \\
\hline
\end{tabular}




\begin{tabular}{|lll|}
\hline Tests & Characteristics & Number (percentage) \\
\hline \multirow{3}{*}{ LBC } & LBC satisfactory & $100(100.0)$ \\
\cline { 2 - 3 } & LBC air artifact & 0 \\
\hline & LBC bloody smear & 0 \\
\hline
\end{tabular}

Table 4: Distribution of study subjects based on cytological results.

\begin{tabular}{|lll|}
\hline Cytological report & Pap smear & LBC \\
\hline Inconclusive & $10(10.0)$ & 0 \\
\hline NILM & $79(79.0)$ & $79(79.0)$ \\
\hline ASCUS & 0 & $9(9.0)$ \\
\hline LSIL & $10(10.0)$ & 0 \\
\hline HSIL & 0 & $11(11.0)$ \\
\hline Squamous cell carcinoma & $1(1.0)$ & $1(1.0)$ \\
\hline
\end{tabular}

Table 5: Correlation of findings of Pap smear and LBC in relation to biopsy findings.

\begin{tabular}{|lll|}
\hline Findings & PAP smear versus biopsy & LBC versus biopsy \\
\hline Observation & & 20 \\
\hline True positive & 11 & 1 \\
\hline False positive & 0 & 0 \\
\hline False negative & 9 & 3 \\
\hline True negative & 4 & 100.0 \\
\hline Correlation & & 75.0 \\
\hline Sensitivity & 55.0 & 95.2 \\
\hline Specificity & 100.0 & 100.0 \\
\hline Positive predictive value & 100.0 & 95.8 \\
\hline Negative predictive value & 30.8 & $<0.001$ \\
\hline Accuracy & 62.5 & \\
\hline P value & 0.04 & \\
\hline
\end{tabular}

Table 6: Studies comparing satisfactory smears by Pap smear and LBC.

\begin{tabular}{|c|c|c|}
\hline Authors & Conventional cytology sample size (\%) & LBC sample size (\%) \\
\hline Shobana et al $^{9}$ & $100(92.0)$ & $100(96.0)$ \\
\hline Sangeeta et al ${ }^{11}$ & $310(92.1)$ & $310(98.39)$ \\
\hline Singh et al ${ }^{12}$ & $94(78.72)$ & $78(92.55)$ \\
\hline Dhananjaya et al ${ }^{14}$ & $97(86.66)$ & $97(88.7)$ \\
\hline Bolick et al $^{15}$ & $39,408(81.14)$ & $10,694(88.16)$ \\
\hline Papillo et al ${ }^{16}$ & $1,8613(86.17)$ & $8,574(93.46)$ \\
\hline Carpenter et al $^{17}$ & $5,000(80.00)$ & $2,727(89.22)$ \\
\hline Diaz-Rosario et al $^{18}$ & $74,573(77.82)$ & $56,095(80.59)$ \\
\hline Weintraub et al ${ }^{19}$ & $1,30,381(72.02)$ & $39,864(91.73)$ \\
\hline Hutchinson et al $^{20}$ & $446(73.54)$ & $446(79.60)$ \\
\hline Lee et $\mathbf{a l}^{21}$ & $7,223(70.62)$ & $7,223(78.31)$ \\
\hline Wang et al $^{22}$ & $972(70.88)$ & $972(79.55)$ \\
\hline Present study & $100(89)$ & $100(100)$ \\
\hline
\end{tabular}

Table 7: Studies comparing sensitivity and specificity of both the techniques.

\begin{tabular}{|c|c|c|c|c|}
\hline \multirow[b]{2}{*}{ Authors } & \multicolumn{2}{|l|}{ Sensitivity } & \multicolumn{2}{|l|}{ Specificity } \\
\hline & $\begin{array}{l}\text { Pap smear } \\
\text { sample size }(\%)\end{array}$ & $\begin{array}{l}\text { LBC } \\
\text { sample size }(\%)\end{array}$ & $\begin{array}{l}\text { Pap smear } \\
\text { sample size }(\%)\end{array}$ & $\begin{array}{l}\text { LBC } \\
\text { sample size (\%) }\end{array}$ \\
\hline Abinaya et al $^{10}$ & $120(39.10)$ & $120(100.0)$ & $120(100.0)$ & $120(100.0)$ \\
\hline Shobana et al ${ }^{9}$ & $100(55.5)$ & $100(83.0)$ & $100(83.7)$ & $100(86.5)$ \\
\hline
\end{tabular}




\begin{tabular}{|c|c|c|c|c|}
\hline \multirow[b]{2}{*}{ Authors } & \multicolumn{2}{|l|}{ Sensitivity } & \multicolumn{2}{|l|}{ Specificity } \\
\hline & $\begin{array}{l}\text { Pap smear } \\
\text { sample size }(\%)\end{array}$ & $\begin{array}{l}\text { LBC } \\
\text { sample size }(\%)\end{array}$ & $\begin{array}{l}\text { Pap smear } \\
\text { sample size }(\%)\end{array}$ & $\begin{array}{l}\text { LBC } \\
\text { sample size (\%) }\end{array}$ \\
\hline Singh et al ${ }^{12}$ & $94(37.3)$ & $94(100.0)$ & $94(84.3)$ & $94(97.29)$ \\
\hline Shanmugapriya et al $^{13}$ & $200(43.37)$ & $200(89.5)$ & $200(95.06)$ & $200(77.16)$ \\
\hline Sherwani et al ${ }^{23}$ & $160(46.3)$ & $160(2.4)$ & $160(50)$ & $160(50)$ \\
\hline Behtash et al $^{24}$ & $506(66)$ & $506(83)$ & $506(86)$ & $506(98)$ \\
\hline Kavatkar et al ${ }^{25}$ & $105(68)$ & $105(76)$ & $105(79)$ & $105(86)$ \\
\hline Present study & $24(55)$ & $24(100)$ & $24(100)$ & $24(75)$ \\
\hline
\end{tabular}

\section{Adequacy of smear}

Among the study subjects, $89 \%$ of Pap smear analysis showed satisfactory smear and $100 \%$ of smears in LBC were satisfactory (Table 3).

\section{Comparison of Pap smear and $L B C$ results}

In Pap smear, inconclusive smears were seen in $10 \%$ cases. NILM (negative for intraepithelial lesion) or malignancy was seen in $79 \%$ of the cases. Cytological abnormality was detected in $11 \%$ of the cases. None of the smears by LBC were inconclusive. NILM was seen in $79 \%$ of the cases. Cytological abnormality was detected in $21 \%$ of the cases (Table 4).

\section{Correlation of findings of Pap smear and $L B C$ in relation to biopsy findings}

Table 5 compares sensitivity, specificity, positive predictive value and negative predictive value of Pap smear and LBC. LBC is consistently better compared to Pap smear in all the above parameters.

\section{DISCUSSION}

The Pap smear has been utilized for cervical cancer screening for more than 50 years. Despite being credited with a $70 \%$ reduction in mortality for cervical cancer, the false negative rate is still a cause for concern. LBC has been developed to address the sampling problems of conventional Pap smear.

In this study the efficacy of LBC was compared with Pap smear in detecting abnormal cervical smears and both the techniques were compared with colposcopy findings or with biopsy when indicated.

Majority (79\%) of the patients included in our study belonged to 4th and 5th decades of life. Similar results were seen in other studies conducted by Shobana et al, Abhinaya et al, Sangeeta et al, Uma et al and Shanmugapriya et al also showed similar results with age of 40 years. ${ }^{8-12}$

Satisfactory parameters like air drying artefact and obscuring blood were absent with LBC when compared to Pap smear ( $9 \%$ and $18 \%$ respectively). This may be because of immersion of cells into the liquid fixative. Only conventional smears were unsatisfactory due to thick smear, which was not a problem with liquid based cytology due to even distribution of cells (Table 6).

Almost all the studies comparing LBC with Pap smear showed similar results. The lower number of unsatisfactory specimens reflects the superiority of the LBC over the conventional method.

Our study showed higher sensitivity and specificity of $100 \%$ and $75 \%$ by LBC when compared to Pap smear (55\% and $100 \%$ respectively) which was concordant to many studies comparing the efficacies of both the techniques. Lower sensitivity of Pap smear which can be explained by the fact that the malignant cells are missed in the smears due to high obscuration of the slides by blood, mucous and air drying artefacts (Table 7).

Positive predictive value and negative predictive value of Pap smear were $100 \%$ and $30.8 \%$ respectively and the same by LBC were $95.24 \%$ and $100 \%$ in our study. Since all the accuracy parameters are better by LBC it can be concluded that LBC is a superior to conventional Pap smear in screening of cervical cancer.

\section{CONCLUSION}

The present study showed that LBC is better in detecting cervical lesions when compared to conventional smear. Hence LBC can be incorporated in clinical practice for routine screening of cervical cancer. It increases the number of satisfactory smears. In addition it has an advantage of collecting material for HPV-DNA test when deemed necessary.

Funding: No funding sources

Conflict of interest: None declared

Ethical approval: The study was approved by the Institutional Ethics Committee

\section{REFERENCES}

1. Ferlay J, Soerjomataram I, Dikshit R, Eser S, Mathers $\mathrm{C}$, Rebelo M, et al. Cancer incidence and mortality worldwide: Sources, methods and major patterns in GLOBOCAN 2012. Int J Cancer. 2015;136(5):35986. 
2. Bray F, Ren JS, Masuyer E, Ferlay J. Global estimates of cancer prevalence for 27 sites in the adult population in 2008. Int J Cancer. 2013;132(5):113345.

3. Mallath MK, Taylor DG, Badwe RA, Rath GK, Shanta V, Pramesh CS, et al. The growing burden of cancer in India: epidemiology and social context. Lancet Oncol. 2014;15(6):205-12.

4. Cuzick J, Arbyn M, Sankaranarayanan R, Tsu V, Ronco G, Mayrand MH, et al. Overview of human papillomavirus-based and other novel options for cervical cancer screening in developed and developing countries. Vaccine. 2008;26(10):29-41.

5. Papanicolaou GN, Traut HF. The diagnostic value of vaginal smears in carcinoma of the uterus. Arch Pathol Lab Med. 1997;121(3):211-24.

6. Nanda K, McCrory DC, Myers ER, Bastian LA, Hasselblad V, Hickey JD, et al. Accuracy of the Papanicalou's test in screening and follow-up of cervical cytologic abnormalities; a systematic review. Ann Intern Med. 2000;132(10):810-9.

7. Strander B, Andersson-Ellström A, Milsom I, Rådberg T, Ryd W. Liquid-based cytology versus conventional Papanicolaou smear in an organized screening program: a prospective randomized study. Cancer. 2007;111(5):285-91.

8. Klinkamer PJJM, Meerding WJ, Rosier PFWM, Hanselaar AGJM, et al. Liquid based cervical cytology. Cancer. 2003;99(5):263-71.

9. Shobana R, Saranya B. Comparison of conventional papanicolaou smear and liquid-based cytology for cervical cancer screening. Int $\mathrm{J}$ Sci Stud. 2019;6(12):64-73.

10. Jeyakumar AM, Mohanapu S. A comparison of cervical cancer screening methods: pap smear, liquid based cytology and VIA VILI. Int $\mathbf{J}$ Reprod Contracept Obstet Gynecol. 2019;8(5):1738-44.

11. Pankaj S, Nazneen S, Kumari S, Kumari A, Kumari A, Kumari J, et al. Comparison of conventional Pap smear and liquid-based cytology: A study of cervical cancer screening at a tertiary care center in Bihar. Indian J Cancer. 2018;55(1):80-3.

12. Singh U, Anjum, Qureshi S, Negi N, Singh N, Goel $\mathrm{M}$, et al. Comparative study between liquid-based cytology and conventional Pap smear for cytological follow up of treated patients of cancer cervix. Indian J Med Res. 2018;147(3):263-7.

13. Shanmugapriya N, Devika P. Comparing the effectiveness of liquid based cytology with conventional PAP smear and colposcopy in screening for cervical cancer and it's correlation with histopathological examination: a prospective study. Int J Reprod Contracept Obstet Gynecol. 2017;6(12):5336-40.

14. Dhananjaya C, Kumari MK. Comparison of manual liquid based cytology and conventional pap smear in cervical cancer screening. Nat $J$ Lab Med. 2017;6(2):32-7.

15. Bolick D, Hellman D. Laboratory implementation and efficacy assessment of the ThinPrep cervical cancer screening system. ActaCytol. 1998;42(1):209-13.

16. Papillo J, Zarka M, John T. Evaluation of the ThinPrep Pap test in clinical practice-a seven-month, 16,314-case experience in Northern Vermont. Acta Cytol. 1998;42(1):203-8.

17. Carpenter A, Davey D. ThinPrep Pap testperformance and biopsy follow-up in a university hospital. Cancer. 1999;87(3):105-12.

18. Rosario LAD, Kabawat SE. Performance of a fluid based thin layer Papanicolaou smear method in the clinical setting of an independent lab and outpatient screening of population in New England. Arch Path Lab Med. 1999;123(9):817-21.

19. Weintraub J, Morabia A. Efficacy of a liquid-based thin layer method for cervical cancer screening in a population with a low incidence of cervical cancer. Diagn Cytopathol. 2000;22(1):52-9.

20. Hutchinson M, Cassin C, Ball H. The efficacy of an automated preparation device for cervical cytology. Am J Clin Pathol. 1991;96(3):300-5.

21. Lee KR, Ashfaq R, Birdsong GG, Corkill ME, McIntosh KM, Inhorn SL. Comparison of conventional Papanicolaou smears and a fluid-based, thin-layer system for cervical cancer screening. Obstet Gynecol. 1997;90(2):278-84.

22. Wang T, Chen H, Yang Y, Tsou M. Comparison of fluid-based, thin-layer processing and conventional Papanicolaou methods for uterine cervical cytology. J Formos Med Assoc. 1999;98(7):500-5.

23. Sherwani RK, Khan T, Akhtar K, Zeba A, Siddiqui FA, Rahman K, et al. Conventional Pap smear and liquid based cytology for cervical cancer screening-a comparative study. J Cytol. 2007;24(4):167-72.

24. Behtash N, Nazari Z, Khaniki M, Zendedel K, Fakor F, Shariat M. Liquiprep a new liquid based cervical cytology method in comparison with conventional pap smear in developing countries; Res J Biolog Sci. 2008;3(6):627-30.

25. Kavatkar AN, Nagwanshi CA, Dabak SM. Study of manual method of liquid-based cervical cytology; Indian J Pathol Microbiol. 2008;51(2):190-4.

Cite this article as: Krishna $\mathrm{C}$, Chandraiah $\mathrm{S}$,

Krishna C. Comparison of conventional

Papanicolaou smear and liquid-based cytology: a study of cervical cancer screening at a tertiary care centre in Bengaluru. Int J Reprod Contracept Obstet Gynecol 2021;10:3106-11. 